\title{
Najnowsze słownictwo a współczesne media elektroniczne, red. R. Pawelec, M. Trysińska, Semper, Warszawa 2008, ss. 174
}

Leksyka związana z mediami bywa często przedmiotem zainteresowań badaczy języka. Powstają różne prace oraz artykuły dotyczące słownictwa używanego w polityce, reklamie czy komentarzach sportowych. Wiele opracowań opisuje język użytkowników internetu. Mimo iż jest to leksyka, z którą spotykamy się na co dzień, często powszechnie znana, nadal stanowi obszar nie do końca zbadany. W tę tematykę wpisuje się książka Najnowsze słownictwo a współczesne media elektroniczne.

Jest to zbiór niezwykle ciekawych tekstów traktujących o języku radia, telewizji i internetu, a autorzy artykułów zwracają uwagę na takie sfery, jak semantyka, frazematyka czy leksykologia. Jak wskazują sami autorzy, zgromadzone w tomie teksty stanowią jedynie niewielką część prac o środkach masowego przekazu, a zwłaszcza na temat dynamicznych zmian, jakie zachodzą w zakresie badanej leksyki.

Omawiana pozycja zawiera dziewięć tekstów o zróżnicowanej tematyce. Poruszają one kwestie bardzo aktualne we współczesnej polszczyźnie i ukazują charakter zmian, jakie dokonują się w języku Polaków.

Pierwszy z artykułów - Przesunięcie semantyczne $w$ nowej leksyce radia i telewizji Wilgi Herman - pokazuje, że media mogą w dużym stopniu wpływać na język Polaków, a polszczyzna ludzi wypowiadających się na przykład w telewizji stanowi dla wielu rodaków wzorzec tego, jak mówić poprawnie. Autorka rozpoczyna tekst zbiorem definicji przesunięcia semantycznego sformułowanych przez różnych autorów, m.in. Władysława Lubasia, Ryszarda Tokarskiego czy Halinę Satkiewicz. Opisują one, czym jest „przesunięcie semantyczne”, jak należy je postrzegać. W dalszej części artykułu (s. 11-30) autorka rozważa następujące kwestie: ,przesunięcia znaczeniowe prowadzące 
do polisemii lub poszerzenia znaczenia wyrazu”, „zmianę kontekstów użycia poprzez zmianę nacechowania stylistycznego”, „hiperbolizację jako źródło zmian znaczeniowych”, „przenośnię jako mechanizm przesunięcia znaczeniowego" oraz „wpływ subkodów na zmiany znaczeniowe”. W każdym z tych podrozdziałów autorka analizuje konkretne wyrazy, przywołując często ich definicje słownikowe, a następnie wskazuje na zmiany semantyczne, jakie dokonują się w polszczyźnie w związku z użyciem konkretnych leksemów, np. klimat, klient. Herman wskazuje również przyczyny tych zmian. Stwierdza, że neosemantyzmy często powstają pod wpływem ekspresji w zakresie potocznej polszczyzny, chęci wyrażania emocji. Wykorzystywane są skojarzenia związane z „,kształtem, funkcją czy uczuciami towarzyszącymi danemu zjawisku" (s. 23). Autorka zauważa też, za Renatą Grzegorczykową, że nacechowanie emocjonalne, w wyniku którego wyraz zyskuje nowe znaczenie, może być tymczasowe. Niewątpliwym walorem tekstu Herman jest bardzo bogata ilustracja materiałowa badanej leksyki, a także szerokie omówienie każdego przykładu, co pozwala czytelnikowi na lepsze zrozumienie opisywanego zjawiska.

Kolejny artykuł - Frazemy w jezyku radia i telewizji - tej samej autorki to niezwykle ciekawy głos w dyskusji na temat frazematyki. Jest to bowiem zagadnienie nie w pełni opisane, a pojęcie frazemu nie do końca sprecyzowane. Artykuł rozpoczyna przegląd stanowisk badawczych opisujących pojęcie „frazem”. Przytoczone zostają różne definicje, np. Wojciecha Chlebdy, Aleksego Awdiejewa, Mirosława Bańki czy Jerzego Bartmińskiego. Przegląd tych koncepcji pozwala wysnuć wniosek, że termin „frazem” nadal nie został w pełni doprecyzowany, a jego definicja stanowi kwestię dyskusyjną. Autorka, wykorzystując ustalenia poprzedników, proponuje własną definicję frazemu, która wyjątkowo trafnie konkretyzuje przywołane pojęcie. Herman zwraca szczególną uwagę na kontekst danej wypowiedzi, różnego rodzaju operatory i stosowane strategie (aksjologiczno-emotywne, behawioralne, informacyjno-weryfikacyjne). Analizowany w tekście zbiór frazemów jest bardzo różnorodny i dobrze udokumentowany.

Język graczy Duel Masters na podstawie polskiej wersji anime „Mistrzowie kaijudo" to artykuł Magdaleny Trysińskiej. Tekst przenosi czytelnika na mało zbadany w językoznawstwie obszar gier komputerowych. Większych prac na ten temat jest niewiele, nie licząc powstających co jakiś czas artykułów, a terminologia stosowana przez graczy to wyjątkowo ciekawe pole do badań językoznawczych, podobnie jak język internetu. Można tam bowiem znaleźć mnóstwo neologizmów lub neosemantyzmów, dowodów na inwencję językową twórców gier czy przykłady nowej leksyki tworzonej przez użytkowników sieci - ich własne, specyficzne słownictwo, nieznane poza określo- 
nymi grupami internautów. Autorka ogranicza się do leksyki używanej przez bohaterów anime, uważa bowiem, że to właśnie ona przenika do terminologii, którą posługują się gracze. Uznaje film animowany za swoistą instrukcję do gry. Badane słownictwo nazywa natomiast nowym żargonem środowiskowym. Najbardziej interesująca jest część, w której badaczka dokonuje analizy poszczególnych komend i zwrotów używanych przez graczy. Wśród badanych wyrazów znajdują się również eufemizmy czy inwektywy. Opisany w artykule materiał jest bardzo ciekawy i nowy dla czytelników, którzy nie są zanużeni w świecie gier. Dowiadują się oni, jak wygląda komunikacja w wirtualnym świecie, jakim jest Duel Masters. Ponieważ internetowa rzeczywistość ma ogromny wpływ na różne grupy społeczne, zwłaszcza, co podkreśla również autorka, na dzieci, tego typu teksty są potrzebne, aby lepiej poznać nowe środowisko, które tworzy się obok tego, w którym żyjemy.

Tekst Ludzie w sieci. Polskie i rosyjskie nazwy osób, których zawód, hobby lub inny rodzaj aktywności sq nierozerwalnie zwiazane z Internetem autorstwa Natalii Ogrodnikowej i Radosława Pawelca również dotyczy internetu. Opisuje nazwy profesji związanych z działalnością w szeroko pojętej sieci. Autorzy analizują polskie i rosyjskie nazwy zawodowe. Pominięte zostały w tekście nazwy typu: informatyk, elektronik, oznaczające według autorów osoby, które moga pracować bez komputera. Jest to jedyny minus artykułu, jednak podyktowany względami technicznymi. Czytelnik zagłębiający się w treść tekstu ze zdumieniem odkrywa, jak duże jest bogactwo różnego typu nazw zawodów związanych z internetem, ile tego typu profesji istnieje. Autorzy zaprezentowali zebrane słownictwo w formie słowniczka, który ma układ gniazdowy: nazwy ogólne, nazwy związane z pracą lub stanowiskiem w wirtualnym świecie, nazwy związane z działalnością niezarobkową, hobbystyczną lub zachowaniami w wirtualnej rzeczywistości, nazwy związane z działalnością nielegalną, nazwy związane z cechami psychicznymi związanymi z posługiwaniem się siecią lub ze sprawnością w poruszaniu się w wirtualnej rzeczywistości (s. 82-89). W obrębie każdej z tych grup zastosowano układ alfabetyczny. Taki układ pomaga łatwo odnaleźć szukany wyraz. Autorzy analizują również rozmaite warianty omawianego słownictwa, sposoby tworzenia nazw żeńskich i słownictwo zapożyczone.

Metaforyczne oblicze Internetu w języku polskim i rosyjskim Natalii Ogrodnikowej kontynuuje tematykę związaną z siecią internetową. Autorka poddaje analizie leksem internet i słusznie zauważa, że „korzystanie z sieci wymagało nazwania wielu nowych czynności i przedniotów. [...] Można powiedzieć, że po zetknięciu się z Internetem użytkownicy zaczęli mówić jego językiem" (s. 99). Ogrodnikowa porusza problematykę metaforyczności niektórych wyrazów i zwrotów używanych w sieci. Metafory dzieli - na podstawie relacji 
między internautą a internetem - na trzy grupy: 1) internet jako narzędzie, 2) internet jako przestrzeń, 3) animizacja i personifikacja internetu. Każdą z grup omawia na przykładach z języka polskiego i rosyjskiego. Podejście komparatystyczne pozwala czytelnikowi spojrzeć na opisywane zagadnienie z szerszej perspektywy.

Tytuł artykułu Małgorzaty Ciunowicz - Polityczne przeboje językowe brzmi zachęcająco nie tylko dla osób zajmujących się językiem polityki. Codziennie bowiem słuchamy wypowiedzi rozmaitych polityków z różnych ugrupowań i wiele z nich, szczególnie teksty zabawne lub wyjątkowo trafne, zadomowiły się w polszczyźnie na zasadzie frazeologizmów. Ciekawa jest zwłaszcza baza materiałowa (oparta na nowym źródle), z której czerpie autorka, co podkreślono już we wstępie do książki. Są to bowiem wyniki sondażu zorganizowanego przez portal „Wirtualna Polska” 21-24 grudnia 2007 roku. Bazę stanowi leksyka żywa, podlegająca ciągłym zmianom, często język użytkowników internetu, co pozwala badać polszczyznę przeciętnego obywatela Polski. Poszczególne wypowiedzi polityków wraz z kontekstami użycia zostały wyszczególnione w kolejnych punktach, opatrzone komentarzem statystycznym i semantycznym oraz przypisane do konkretnych osób. Niewątpliwą zaletą tego artykułu jest przejrzysta prezentacja materiału, która pozwala czytelnikowi prześledzić funkcjonowanie danego frazeologizmu.

Dwa kolejne artykuły, napisane przez Monikę Skarżyńską, poruszają problematykę reportażu telewizyjnego, który w ostatnich latach stał się bardzo popularny. W pierwszym z nich, zatytułowanym Język prawników w shużbie reportażu telewizyjnego, autorka szeroko omawia problematykę reportażu jako gatunku, a następnie wskazuje konkretne wyrazy prawnicze pojawiające się w tego typu relacjach wraz z ilustracją materiałową. Bogactwo i zróżnicowanie tej leksyki oraz jej dobór tłumaczy specyfiką tematyki poruszanej w reportażach, pewną oficjalnością sytuacji, okolicznościami oraz intencją wypowiadania się, a także, za Aleksandrem Wilkoniem, wpływem między innymi języka urzędowych komunikatów czy tekstów popularnonaukowych. Badane słownictwo dzieli na grupy ze względu na proweniencję, np. wyrazy stricte prawnicze, neutralne, kolokwialne, elementy stylu naukowego, urzędowego. Zwraca również uwagę na funkcję informacyjną tego typu leksyki i wskazuje, że terminologia prawnicza to tylko jeden z elementów reportażu.

Drugi z artykułów Skarżyńskiej został zatytułowany Slowo pisane a/i stowo mówione. Ikoniczność reportażu telewizyjnego. Autorka poprzedza swoje rozważania ciekawymi refleksjami na temat początków komunikacji i rozwoju języka. Zwraca uwagę na fakt, że nie tylko słowo, ale również obraz służą do porozumiewania się od początku istnienia cywilizacji ludzkiej, a na potwierdzenie przywołuje słowa Marka Hendrykowskiego: słowo jest ,jednocześnie 
obrazowe i dźwiękowe, wizualne i audialne [...], współtworzy pewną całość audiowizualną w każdym konkretnym akcie komunikacyjnym, w którym się pojawia” (s. 144). Autorka celem swojego tekstu czyni ,analizę wzajemnych relacji słowa mówionego i pisanego oraz ich oddziaływania na obrazowość" (s. 145). Bazę materiałową stanowią reportaże z Magazynu Ekspresu Reporterów. Skarżyńska rozpatruje obrazy ruchome i statyczne oraz obecność tekstu pisanego w przekazie telewizyjnym. Rozważania na ten temat prowadzą autorkę do wniosków, że większy udział słowa pisanego w mediach zmusza odbiorcę komunikatu do większego skupienia.

Ostatni artykuł w tomie - Wymiary potoczności - autorstwa Radosława Pawelca i Magdaleny Trysińskiej jest swego rodzaju podsumowaniem zaprezentowanej w książce problematyki. We wszystkich tekstach czytelnik ma bowiem do czynienia ze słownictwem stosunkowo nowym w polszczyźnie, często tworzonym przez przeciętnych użytkowników języka i ocierającym się o potoczność. Autorzy tekstu dokonują przeglądu definicji pojęcia „potoczność" na podstawie dawnych słowników, aby dalej przejść do omówienia tej kategorii w pracach współczesnych językoznawców i w najnowszych klasyfikacjach. Tego typu analiza ma dużą wartość metodologiczną dla badaczy kolokwializmów w polszczyźnie. Swoje wnioski badacze opierają na obserwacji języka mediów i stwierdzają że obecnie nastapiła zmiana w pojmowaniu kategorii potoczności i oficjalności, a ważną rolę odgrywa poczucie językowe osób posługujących się polszczyzną. Za Władysławem Lubasiem dostrzegają że potocyzmy pełnią funkcję fatyczną (by pozyskać odbiorcę), zwłaszcza w reklamie i polityce, oraz ludyczną w programach typu talk-show. Zauważają również, że jest to proces dwustronny, następuje bowiem „mediatyzacja świata i języka potocznego" (s. 168-169), a proces ten ,przejawia się [...] w zmianach nie tyle stricte językowych, co raczej zmianach społecznych, obejmujących zwyczaje, sposób życia itd. [...]. Mediatyzacja języka potocznego dokonuje się na poziomie struktur leksyki, ale także [...] bezpośrednio na poziomie rozrostu pól semantycznych pojęć związanych z mediami, a także na poziomie statystyki" (s. 169-172).

Książka Najnowsze stownictwo a wspótczesne media elektroniczne to zbiór artykułów podejmujących problematykę związaną z najnowszymi zjawiskami w języku. Główne źródła materiału stanowią telewizja oraz internet, czyli media, które mają ogromny wpływ na życie współczesnego człowieka, zwłaszcza młodego, najbardziej kreatywnego językowo, i na jego sposób wypowiadania się. Jest to pozycja godna uwagi, opisująca żywe procesy zachodzące w języku polskim. Książka ma walor naukowy, gdyż zawiera informacje dotyczące na przykład nieopisanego dotąd w pełni języka internetu, a zwłaszcza słownictwa gier komputerowych. Jej niewątpliwą zaletą jest bogata dokumentacja mate- 
riałowa pozwalająca zobaczyć, w jakich kontekstach pojawia się omawiana leksyka, i stanowiąca doskonałe uzasadnienie dla omawianych tez.

Do przeczytania książki zachęca również szata graficzna i przejrzysty układ tekstu. Poszczególne rozdziały, podrozdziały czy ważne wyrazy zostały wyróżnione, a sposób prezentacji materiału w kolejnych artykułach pozwala na szybkie odnalezienie szukanej treści.

Książka Najnowsze słownictwo a wspótczesne media elektroniczne jest pozycją godną polecenia wszystkim zainteresowanym najnowszymi zjawiskami w polszczyźnie.

Kinga Zalejarz 